\title{
Study of the decentralized electrification by a micro- wind power plant: Case of Ahouandji locality in southern Benin
}

Hagninou E. V. Donnou ${ }^{1,2}$ [https://orcid.org/0000-0002-2207-0398] , Gabin Koto N'Gobi 1,2 [https://orcid.org/0000-00017322-138X] , Hilaire Kougbéagbédè 2 [https://orcid.org/0000-0002-1962-9680], Germain Hounmenou ${ }^{3}$, Aristide

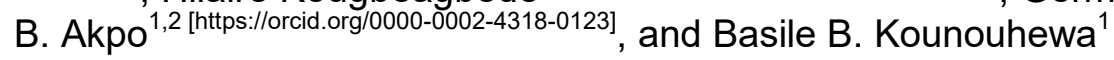

${ }^{1}$ Laboratoire de Physique du Rayonnement (LPR), Université d'Abomey-Calavi, 01 BP 526 Cotonou

${ }^{2}$ Laboratoire de Physique de l'Atmosphère (LPA), Université d'Abomey-Calavi, 01 BP 526 Cotonou

${ }^{3}$ Institut National Supérieur de Technologie Industrielle, Université Nationale des Sciences, Technologies, Ingénieries et Mathématiques, Abomey, Bénin

\begin{abstract}
Access to energy is a major challenge for the socio-economic well-being of populations. In Benin, the electric energy sector is characterized by a low rate of access to energy in rural area (6.6\% in 2017) and dependence on the outside at $40 \%$. In the village of Ahouandji (Ouidah commune) located on the coast of Benin and far from the conventional network, the surface winds are regular and permanent. However, this wind resource is untapped despite the unavailability of electrical energy. To cope with this difficulty, this study therefore addresses the design and sizing of a micro-wind power plant to supply the region. Wind data at $10 \mathrm{~m}$ above the ground recorded over the period January 1981 to December 2014 by the Agency for the Safety of Air Navigation in Africa (ASECNA) were used. Based on the socio-economic study of the locality and the statistical study of the winds by the Weibull distribution and the power law, the sizing of the wind power plant components was carried out. The economic study of the system then made it possible to assess the profitability of the project. It emerges from this study that at $25 \mathrm{~m}$ above the ground the Weibull shape parameter is estimated at 2.94 and the scale parameter at $6.07 \mathrm{~m} / \mathrm{s}$. The most frequent speed is estimated at $5 \mathrm{~m} / \mathrm{s}$ and the one giving the maximum energy at $10.2 \mathrm{~m} / \mathrm{s}$. The micro-power plant is made up of two wind turbines with a nominal power of $29.7 \mathrm{~kW}$ for a daily production estimated at $355 \mathrm{kWh}$, a three-phase converter rated at $30 \mathrm{~kW}, 06$ inverters/chargers with a power of $11.5 \mathrm{~kW}$ and 120 batteries (3000Ah/2V). The selling price of kilowatt-hour estimated at 0.17 euro/kWh is quite competitive. The establishment of this micro-wind power plant is therefore an asset for these rural populations.
\end{abstract}

Keywords: Electrical energy, Weibull distribution, Power law, Wind turbine, Kilowatt-hour price

\section{Introduction}

Energy plays an essential role in the socio-economic development of people and its demand is growing exponentially in the world [1], [2]. In order to reconcile development policies in this sector with environmental protection strategies, renewable energies now constitute a sustainable alternative. Their share in the global energy mix has been steadily increasing [3], [4] and they will become the largest source of electricity generation by 2025 , surpassing coal according to the International Energy Agency's Renewable Energy 2020 report (IEA, 2020). Among these sources, wind power has experienced a remarkable growth in recent decades. Its production capacity has increased from 23,900 MW in 2001 to $591,549 \mathrm{MW}$ at the end of 2018 [5], [6], [7] and wind power production exceeded 1,200 TWh over the year 2018, 
contributing to $4.6 \%$ of the world's electricity production (all sources combined) [7]. This source therefore deserves to be valorized especially in developing countries. Moreover, the production of electricity in rural communities is an acute problem that militates against the socio-economic well-being of the population of these underdeveloped countries [8], [9].

In Benin, several studies such as Awanou et al [10], Houekpoheha et al [11], Akpo et al [12],Salami et al [13], Donnou et al [2] agree that the exploitation of wind energy in the coastal region is suitable at small and large scale. However, despite the many efforts made by leadersin the energy sector, this source of energy is still not exploited and many rural areas still livewithout electricity, especially on the coast of Benin. The electrification rate in rural areas is $6.6 \%$. To cope with these challenges of electricity production, several authors have addressed the issue of rural electrification through the installation of micro wind power plants or the assessment of wind potential to overcome the energy deficit observed in these regions especially rural. Thus, in the work of Abdelhady et al [14], the authors give an overview of the wind potential in different regions of Egypt, along the Mediterranean and the Red Sea, and in the Western Desert. The techno-economic evaluation of the annual electricity production from 8 small wind turbines was performed. The net present value and payback period by analyzing the profitability of the selected wind turbines were addressed. The results obtained show that, in the locations considered, the reduced value of the feed-in tariff is a detrimental factor affecting the profitability of small wind turbines. Okeniyi et al [8] studied the assessment of wind power potential at selected sites in three major geopolitical zones in Nigeria. It was found that the simulation of electrical energy at different hub heights of low wind speed wind systems showed that the cost of electrical energy production at the three study sites converged to an affordable cost per kWh of electrical energy (0.0507 Euro in Kaduna, 0.0774 Euro in Warri and 0.0819 Euro in Calabar). Rural electrification by renewable energy source (wind) in these study sites was suggested by the authors. Ajayi et al [15] evaluated the wind power potential of two sites (Shaki, Iseyin) in Oyo State, Nigeria. Three wind energy conversion systems were used and it was found from the statistical study of the winds, that the sites have a capacity to generate in MWh and GWh of electricity at an average cost/kWh between (0.025 and 0.049) Euro. Furthermore, turbines with technical parameters of start-up speed, cut-off speed and rated speed $(3 \mathrm{~m} / \mathrm{s}, 25 \mathrm{~m} / \mathrm{s}$ and $11.6 \mathrm{~m} / \mathrm{s})$ are suitable for these sites. In Turkey, Gökçeka et al [16] analyzed the wind energy potential of Kirklareli province in the northwestern Marmara region. The economic evaluation of wind energy at the site was performed using the discounted cost method. The results showed that the energy production cost per $\mathrm{kWh}$ for the site concerned varies between 0.0537 and 0.119 euro and that an increase in operation and maintenance costs from 0 to $10 \%$, leads to an increase in the unit energy cost of about $6 \%$. Similarly, the analysis of the wind characteristics in the city of Ras Benas located on the east coast of the Red Sea in Egypt using measured data (wind, pressure and temperature) and the Weibull function was performed by Ahmed [17]. This station has a huge potential of wind power for electricity generation and was selected to install a wind farm of $30 \mathrm{MW}$ consisting of 20commercial wind turbines (Nordex S 77). The production costs have been estimated at 0.013 euro/kWh, which is a competitive price in the global wind energy market. In the work of Ajayi et al [18], a study assessed the wind power potential of ten selected sites in the southwestern region of Nigeria and conducted a cost-benefit analysis of wind power generation at these sites. The energy cost analysis shows that the production cost can be as low as 0.02 Euro/kWh and as high as 5.03 Euro/ kWh, depending on the turbine model used. Faida et al [19], after processing and simulating wind data from a site in Morocco, designed a wind farm and evaluated its electrical production based on a judicious choice of wind turbines. The installed capacity is $140 \mathrm{MW}$, i.e. 140 wind turbines, for an annual production of $516.6 \mathrm{GWh}$. Kassem et al [20] undertook an economic evaluation of a grid-connected $12 \mathrm{MW}$ wind farm and PV plant in two regions of northern Cyprus for electricity generation. The production costs of the wind farm obtained by the authors ranged from 0.023 to 0.04 Euro/kWh. Gaddada and Kodicherla [21] selected three commercial wind turbines as large-scale wind energy conversion systems (WECS) for the technical evaluation of power generation through the present value cost (PVC) method in eight selected locations in the Tigray region of Ethiopia. The minimum average cost per kWh obtained in Mekele was $\$ 0.0011 / \mathrm{kWh}$ with VESTAS 
V110-2. while the highest average cost was $\$ 7.3148 / \mathrm{kWh}$ with POLARIS P15-50 in Shire. Bagiorgas et al [22] estimated the Weibull parameters by three different methods on four meteorological stations in the central region of Western Greece to estimate the wind potential in this area. An analysis of the specific cost per kilowatt-hour of electrical energy, obtained for several wind turbines at different hub heights was performed for each station. The result of this study is that the specific cost per kWh decreases as the size of the wind turbine increases for comparable systems designed by the same manufacturer with similar performance but with different power ratings (size).

The diversity of this work and the results obtained, notably on the competitive cost of the wind power kilowatt-hour, reveal the interest in this energy source and the importance of its exploitation on appropriate sites for a better profitability. The interest of this study, which consists of supplying electric energy from a wind source to the households of Ahouandji, is therefore justified in this locality. To achieve this, a statistical study of wind speeds in the study area was conducted at 10 and $25 \mathrm{~m}$ to estimate the available wind resource. Then, based on the socio-economic study of the Ahouandji locality and the wind speed profile, the characteristics of the components of the micro power plant were determined. Finally, the financial evaluation of the project was carried out in order to assess its profitability.

\section{Material and Methods}

\section{Material}

\section{Study area}

Benin's $125 \mathrm{~km}$ long coastal zone extends from Hillacondji in the west to Kraké in the east. It is located between latitude $6^{\circ} 15$ ' $\mathrm{N}$ and $7^{\circ} \mathrm{O} 0^{\prime} \mathrm{N}$ and longitude $1^{\circ} 40^{\prime} \mathrm{E}$ and $2^{\circ} 45^{\prime} \mathrm{E}$. The site of our study is the village of Ahouandji located in the district of Avlékété (commune of Ouidah) on the coast of Benin. Figure 1 provides an overview of the geographical location of the coastal region of Benin and the study site.

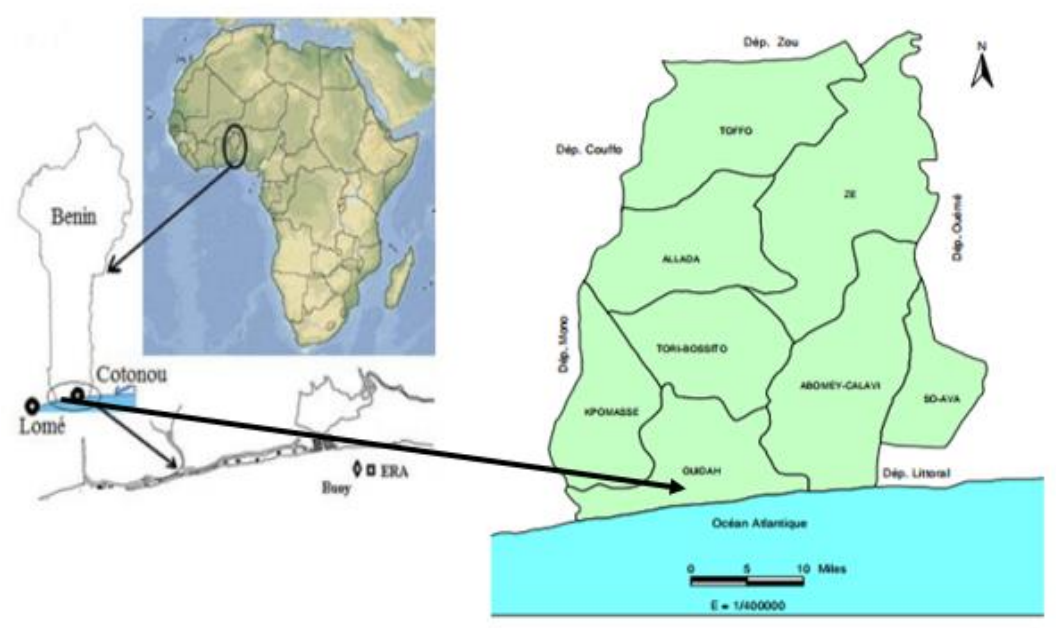

Figure 1. Geographic location of the coastal region of Benin. Location of the commune of Ouidah [23], [24].

\section{Data collection}

The data used in this study include wind speed measured at $10 \mathrm{~m}$ from the ground during the period from January 1981 to December 2014. They were recorded every hour by the Cotonou Airport meteorological station. Figure 2 shows the experimental site of the meteorological station where the data were collected. 

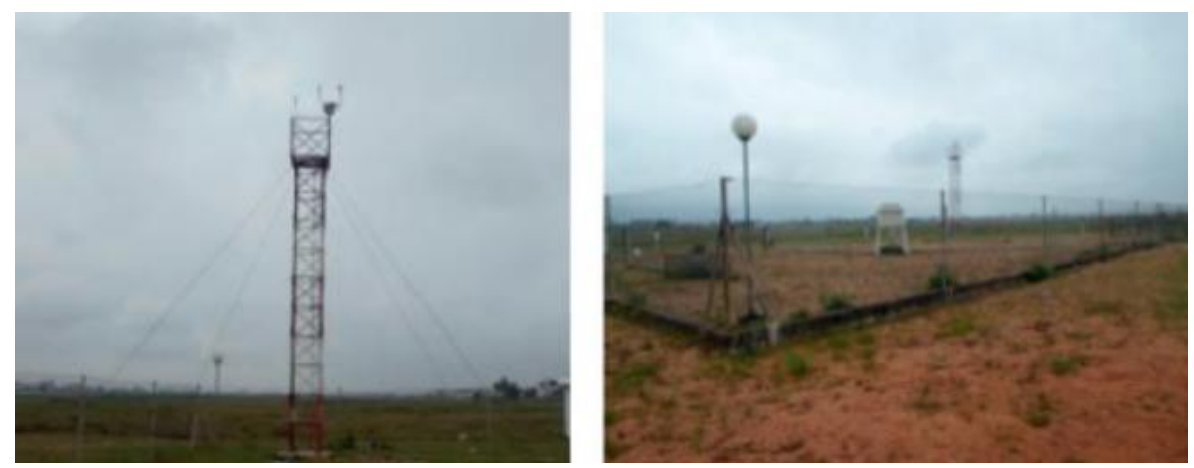

Figure 2. Experimental site of the Cotonou-Airport meteorological station. Anemometer with cup and wind vane located on a $10 \mathrm{~m}$ mast (left panel). Experimentation site (right panel) [25]

\section{Methods}

\section{Statistical study of the wind at the study site}

\section{Weibull distribution}

The Weibull function is used to characterize the frequency distribution of wind speeds over a given period (a year, a month, or a day). It is defined by equation [2], [17], [26], [27], [28], [29]:

$$
f(v)=\frac{k}{c}\left(\frac{V}{C}\right)^{k-1} \exp \left[-\left(\frac{V}{C}\right)^{k}\right]
$$

With $f(v)$ the Weibull probability density function which is the probability of observing a wind speed $V$ in $\mathrm{m} / \mathrm{s}, \mathrm{c}$ in $\mathrm{m} / \mathrm{s}$ is the scale factor of the Weibull distribution. It is related to the mean wind speed by the Weibull form factor $k$ describing the wind speed distribution. The relationship between the scale factor of the Weibull law and the mean wind speed is established by the following formula [2], [11], [12], [22]:

$$
\mathrm{C}=\frac{\mathrm{V}}{\Gamma\left(1+\frac{1}{\mathrm{k}}\right)}
$$

With $\Gamma$ the Gamma function, $\vee$ the average wind speed. The relationship to determine the form factor is given by [11], [12], [19], [30]:

With $\sigma$ the standard deviation.

$$
\mathrm{k}=\left(\frac{\sigma}{\mathrm{V}}\right)^{-1.086}
$$

The velocity giving the maximum energy $V_{m e}$ and the most frequent velocity $V_{f}$ on the site are given by [2], [18]:

$$
\begin{aligned}
\mathrm{V}_{\mathrm{me}} & =\left(1+\frac{2}{\mathrm{k}}\right)^{1 / \mathrm{k}} \mathrm{c} \\
\mathrm{V}_{\mathrm{f}} & =\left(1-\frac{1}{\mathrm{k}}\right)^{1 / \mathrm{k}} \mathrm{c}
\end{aligned}
$$

\section{The power law}

The power law is an equation that allows to determine from a known wind speed data (usually $10 \mathrm{~m}$ from the ground), the speed at an altitude higher than $10 \mathrm{~m}$. It is the most commonly used equation for the extrapolation of wind speeds [25]. It is given [25], [31], [32], [33], [34]. 


$$
\mathrm{V}_{2}=\mathrm{V}_{1}\left(\frac{\mathrm{z}_{2}}{\mathrm{z}_{1}}\right)^{\alpha}
$$

with $z_{1}$ the height of the initial observation of the wind speed $(m), V_{1}$ is the observed speed ataltitude $z_{1}, z_{2}$ is the height at which we want to estimate the wind speed $(m), V_{2}$ is the speed that we estimate at the height $z_{2}(\mathrm{~m} / \mathrm{s})$.

\section{Sizing of the micro wind power plant}

The energetic study of the micro wind power plant consists in sizing the different components necessary for the implementation of the plant. It is thus a question of determining:

- the socio-economic study of the locality to be supplied;

- the power of the wind farm to be set up and able to cover the energy needs;

- the capacity of the batteries to be installed while taking into account the number of days or hours of autonomy;

- the characteristics of the converters to be used to satisfy the electrical energy needs;

- the system protection and control devices

\section{Socio-economic study of the locality of Ahouandji}

The socio-economic study of the Ahouandji locality was carried out according to the following steps

\section{Data collection}

First, a study of the number of inhabitants of the Ahouandji village was conducted. Indeed, from the notebooks of villages and city districts of the Atlantic department published by the National Institute of Statistics and Economic Analysis (INSAE) [24], the population of the said village in the years 2004 and 2013 was obtained. In order to estimate the current number of inhabitants of the village considered in this study, we extrapolated from the year 2004 to the year 2020 using the following expression [24]:

$$
P_{2020}=P_{2004}(1+\tau)^{(m-a)}
$$

With $m$ the future year (2020), a : the base year (2004).

The rate of increase $\tau$ is determined by [24]:

$$
\tau=\left(\frac{\mathrm{P}_{2013}}{\mathrm{P}_{2004}}\right)^{\frac{1}{\mathrm{~m}}}-1
$$

Avec $\mathrm{P}_{2013}$ : Population in 2013= 851 inhabitants

$P_{2004}$ : Population in $2004=566$ inhabitants

$m: 2013-2004$

The number of persons being estimated on average at 6 per household from the field surveys, we have the number of household $\mathrm{N}$ which is given by:

$$
\mathrm{N}=\frac{\mathrm{P}_{2020}}{6}
$$

In view of the demographic data obtained from the extrapolation to the year 2020, in this case the number of households, we have constituted a sample of households to be surveyed in the locality. The size of the sample is determined from the following relationship [24]:

$$
\mathrm{n}_{\mathrm{e}}=\mathrm{t}^{2} * \mathrm{p} *(1-\mathrm{p}) / \alpha^{2}
$$


With $\mathrm{n}_{\mathrm{e}}$ the minimum sample size for obtaining significant results for a given event and risk level, $t$ the confidence level (the standard value of the $95 \%$ confidence level will be 1.96 ), $p$ the estimated proportion of the number of households that have the characteristic $(10 \%$ of the total number of households), $\alpha$ the margin of error (usually $5 \%$ ). Based on the sample size of the population, a field survey was conducted in these households to learn about their different energy needs.

\section{Analysis of collected data}

The analysis of the data consisted in making a synthesis of the receivers used by the households with their respective powers and then to proceed to the energy balance.

\section{Power of the wind farm}

To determine the power of the wind farm, the daily energy needs of the population must be less than or equal to the daily energy produced by the wind turbines. The useful energy $E_{u}$ provided by the wind farm to supply the locality was obtained from equations (11), (12) and (13):

$$
\mathrm{E}_{\mathrm{u}}=\mathrm{P}_{\mathrm{u}} * \mathrm{~T}
$$

Its useful power $\mathrm{P}_{\mathrm{u}}$ is given by the formula [9], [22]:

$$
\mathrm{Pu}=\mathrm{fc} \mathrm{P}_{\mathrm{n}}
$$

With:

$$
\mathrm{fc}=\left\{\frac{\exp \left[-\left(\frac{\mathrm{V}_{\mathrm{d}}}{\mathrm{c}}\right)^{\mathrm{k}}\right]-\exp \left[-\left(\frac{\mathrm{V}_{\mathrm{n}}}{\mathrm{c}}\right)^{\mathrm{k}}\right]}{\left(\frac{\mathrm{V}_{\mathrm{n}}}{\mathrm{c}}\right)^{\mathrm{k}}-\left(\frac{\mathrm{V}_{\mathrm{d}} \mathrm{c}}{\mathrm{c}}\right)^{\mathrm{k}}}-\exp \left[-\left(\frac{\mathrm{V}_{\mathrm{c}}}{\mathrm{c}}\right)^{\mathrm{k}}\right]\right\}
$$

fc is the capacity factor, $P_{n}$ is the nominal power (W), T is the time $(h), V_{d}$ is the starting speed, $V_{n}$ he nominal speed and $V_{c}$ the stop speed. The choice of $V_{n}$ is made from the speed $\mathrm{V}_{\mathrm{me}}$ and $\mathrm{V}_{\mathrm{f}}$. We have then $\mathrm{V}_{\mathrm{f}}<\mathrm{V}_{\mathrm{n}} \leq \mathrm{V}_{\mathrm{me}}[8]$.

\subsubsection{Battery capacity}

The capacity $\mathrm{C}_{\mathrm{b}}$ in Ah of the battery bank is determined by the following relationship [35]:

$$
\mathrm{C}_{\mathrm{b}}=\frac{\mathrm{E}_{\mathrm{cons} *} \mathrm{~N}}{\mathrm{D} * \mathrm{U}}
$$

With $\mathrm{E}_{\text {cons }}$ the total daily energy to be satisfied, $\mathrm{N}$ number of autonomy days equal to 2 in the case of this study, $\mathrm{D}$ the deep discharge of the battery $(80 \%), U$ the battery voltage is fixed at $48 \mathrm{~V}$ in this study.

\section{Characteristics of converters}

\section{$>$ Sizing of the DC/AC converter}

The use of an inverter in the wind power plant is essential because the loads will be supplied with alternating current. Indeed, its dimensioning is done essentially on the basis of the nominal power supplied by the wind field. Thus, the power of the DC/AC converter is equal to the power of the wind field.

\section{$>$ Sizing of the battery charger inverter}

The battery charger inverter is an essential device in a wind power plant, since it not only allows to recharge the batteries that will be used as energy source for the loads during the periods when there is not enough wind, but also to create a primary AC voltage network 
related to the synchronization of the central converter (DC/AC). It is usually sized based on the maximum power demand of the load. In fact, it is desirable to apply a safety coefficient equal to 1.25 to the maximum basic power in order to have a wide power range. The power of the inverter is given by [35]:

$$
\mathrm{P}_{\mathrm{ond}}=\frac{\mathrm{P}_{\max } * 1.25}{\eta}
$$

With $\mathrm{P}_{\max }$ the maximum power demand, $\mathrm{P}_{\text {ond }}$ is the power of the inverter, $\eta$ is the efficiency of the inverter (98\%).

\section{Economic calculation}

\section{Calculation of the annuity}

The annuity which represents the annual repayment of a loan with interest by a constant amount is given by the relation [35]:

$$
\mathrm{A}=\frac{\mathrm{Ii}}{1-(1+\mathrm{i})^{-\mathrm{n}}}
$$

With I : Initial investment, i Interest rate (12\% in the case of this study), $\mathrm{n}$ Lifetime of the plant components (between 10 and 25 years).

\section{Overall discounted cost}

This cost takes into account maintenance, operating costs and annuity. Maintenance and operating costs are estimated at between 3 and $5 \%$ of the initial investment cost of the plant.

$>$ Calculation of the cost per kilowatt hour

The cost per kilowatt-hour is given by the ratio of the discounted gbobal cost $\mathrm{Cg}$ to the annual energy production $\mathrm{P}_{\mathrm{E}}$ [35]:

$$
\mathrm{C}_{\mathrm{k}}=\frac{\mathrm{C}_{\mathrm{g}}}{\mathrm{P}_{\mathrm{E}}}
$$

\section{Return on investment time}

Also known as the payback period, this is the time that must elapse before the operating profit streams can fully cover the initial capital. The initial investment is divided by the empirical average of the annual cash flows (profits). Then, we multiply the remainder of the quotient thus obtained by 360 days.

\section{Results and discussion}

\section{Wind speed distribution}

\section{Variation of the Weibull parameters}

In Figure 3, the Weibull shape $\mathrm{k}$ and scale c parameters are shown at the monthly scale. 

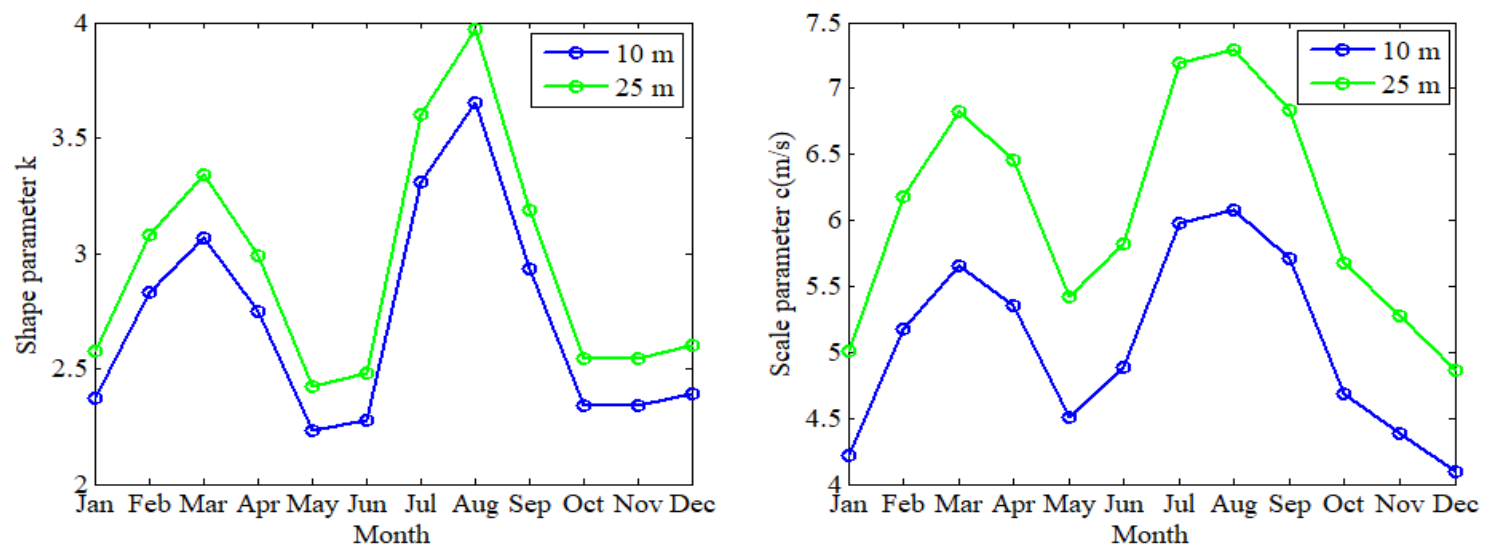

Figure 3. Monthly variation of Weibull parameters at $10 \mathrm{~m}$ from the ground (1981-2014)

We note that both Weibull parameters show seasonal variation. The shape parameter $\mathrm{k}$ varies from 2.23 (May) to 3.65 (August) at $10 \mathrm{~m}$ and from 2.3 (May) to 3.98 (August) at $25 \mathrm{~m}$. As for the scale parameter c, it varies from $4.10 \mathrm{~m} / \mathrm{s}$ (December) to $6.08 \mathrm{~m} / \mathrm{s}$ (August) at 10 $\mathrm{m}$ and $4.75 \mathrm{~m} / \mathrm{s}$ (December) to $7.30 \mathrm{~m} / \mathrm{s}$ (August). The highest values of $\mathrm{k}$ are observed during the windiest months while the lowest are obtained during the least windy months. These results are in agreement with the work of Donnou et al [2] who used wind data at a smaller time scale (every 10min) in the same study area.

\section{Speed giving the maximum energy}

Figure 4 shows the monthly variation of the wind speed giving the maximum energy at altitudes of 10 and $25 \mathrm{~m}$ above ground.

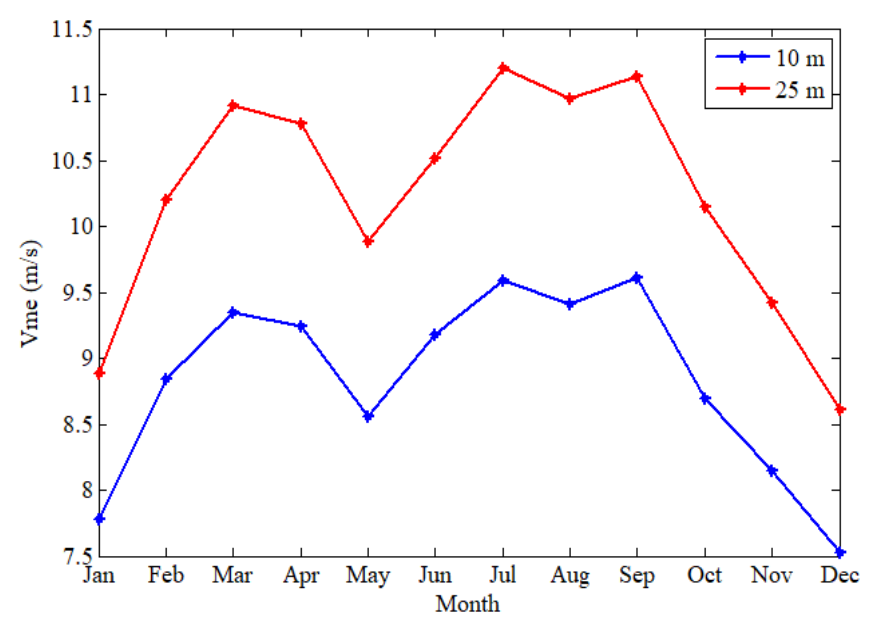

Figure 4. Variation of the wind speed giving the maximum energy as a function of the altitude (1981-2014)

The wind speed giving the maximum energy varies from $7.53 \mathrm{~m} / \mathrm{s}$ (December) to $9.60 \mathrm{~m} / \mathrm{s}$ (September) at $10 \mathrm{~m}$ and from $8.61 \mathrm{~m} / \mathrm{s}$ (December) to $11.19 \mathrm{~m} / \mathrm{s}$ (July) at $25 \mathrm{~m}$. Referring to the studies of Adaramola et al [36], the wind speed carrying the maximum energy were evaluated at the coastal sites of Adafoah, Anloga, Aplaku, Mankoadze, Oshiyie and Warabeba in Ghana and are respectively estimated at $8.46 \mathrm{~m} . \mathrm{s}^{-1}, 7.18 \mathrm{~m} . \mathrm{s}^{-1}, 6.81 \mathrm{~m} . \mathrm{s}^{-1}, 6.82$ $\mathrm{m} . \mathrm{s}^{-1}, 5.79 \mathrm{~m} . \mathrm{s}^{-1}$ and $6.5 \mathrm{~m} . \mathrm{s}^{-1}$ at $12 \mathrm{~m}$. These values obtained are close to those obtained at our site at $10 \mathrm{~m}$ from the ground, notably at Adafoah and Anloga.

\section{Variation of the Weibull distribution}

The variation of the Weibull probability function at $10 \mathrm{~m}$ and then at $25 \mathrm{~m}$ from the ground is shown in Figure 5. 


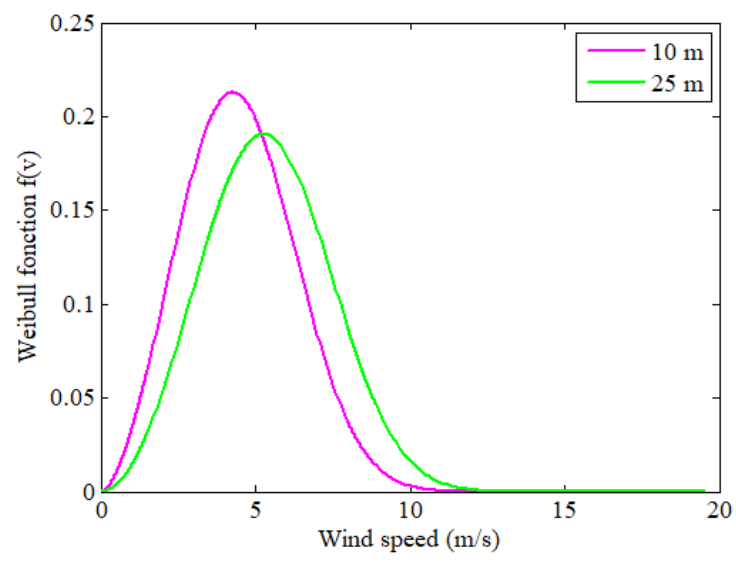

Figure 5. Annual frequency distribution of wind speeds from Weibull model (19812014)

Analysis of Figure 5 indicates that the most frequent wind speed at the study site is estimatedto be $4 \mathrm{~m} / \mathrm{s}$ at $10 \mathrm{~m}$. A large proportion of the winds above $10 \%$ are between $2 \mathrm{~m} / \mathrm{s}$ and $7 \mathrm{~m} / \mathrm{s}$. Wind speeds above $10 \mathrm{~m} / \mathrm{s}$ have a frequency of occurrence of less than $1 \%$. At $25 \mathrm{~m}$, the most frequent wind speed is $5 \mathrm{~m} / \mathrm{s}$. Wind speeds above $12 \mathrm{~m} / \mathrm{s}$ have a frequency of less than $1 \%$. Wind speeds between 3 and $8 \mathrm{~m} / \mathrm{s}$ have a frequency of occurrence of more than $10 \%$. We also notice that the most frequent speeds on the site are different from those that carry the maximum energy. These results are confirmed by the work of d'Adaramola et al [36] who obtained on the coastal sites of Adafoah, Anloga, Aplaku, Mankoadze, Oshiyie and Warabeba in Ghana frequent velocities of $4.23 \mathrm{~m} . \mathrm{s}^{-1}, 3.59 \mathrm{~m}^{-1} \mathrm{~s}^{-1}, 4.34 \mathrm{~m} . \mathrm{s}^{-1}, 3.88 \mathrm{~m} . \mathrm{s}^{-}$

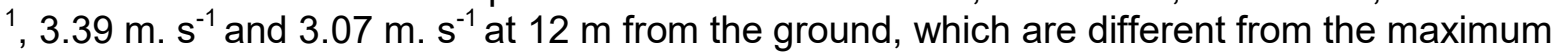
energy speeds obtained at the same sites. The values of the most frequent wind speed observed on the Beninese coast were then compared to those recorded on some coastal sites of the West African sub-region. Thus, in analyzing the work of Udo et al [37] who investigated the wind energy potential of four coastal sites in Nigeria, the authors observed that the most frequent wind speed expected in Calabar, Uyo, Warri and Ikeja is about $3 \mathrm{~m} / \mathrm{s}$, $4.5 \mathrm{~m} / \mathrm{s}, 3.5 \mathrm{~m} / \mathrm{s}$ and $5 \mathrm{~m} / \mathrm{s}$. Similarly, in the work of Youm et al [38], the authors evaluated the wind potential on the northern coast of Senegal along the Atlantic Ocean, particularly at the sites of Mboro, Ndandekhou, Pékesse, Pôtou and Makhana. The observed frequencies increase steadily, reaching a maximum value of wind speed of $4 \mathrm{~m} / \mathrm{s}$ especially at the sites of Pôtou, Mboro and Makhana which are near the coast and where sea breezes can influence the wind regime. It can be seen that these values obtained on these Nigerian and Senegalese coastal sites at $10 \mathrm{~m}$ above ground level are close to those observed in Cotonou.

\section{Characteristics of the micro wind power plant}

\section{Energy balance of the Ahouandji locality}

Figure 6 presents the results of the socio-economic survey. Thirteen households represent the sample surveyed at the site out of a total of 195 households in the village. The energy and power balance for this sample of households is presented in Figure 6. 

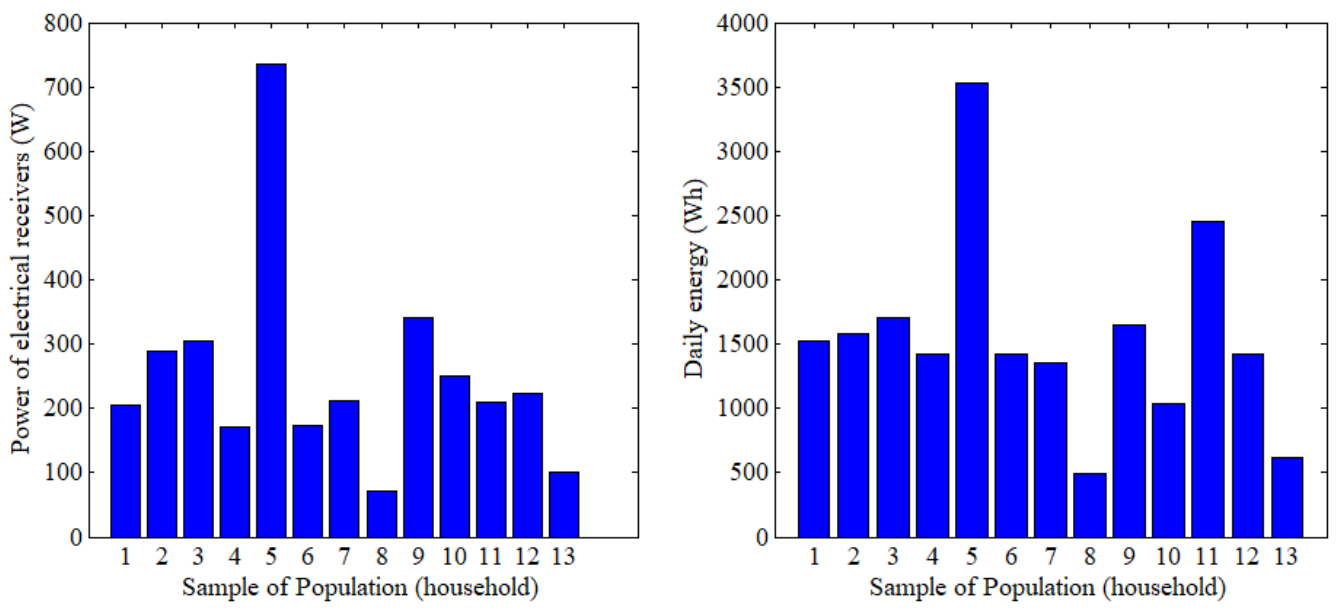

Figure 6. Energy balance by household sample

It can be seen that the energy requirements vary from one household to another. The total power of the receivers varies from $71 \mathrm{~W}$ to $736 \mathrm{~W}$ and the average daily energy consumption from $616 \mathrm{Wh}$ to $2456 \mathrm{Wh}$. The power and energy that would be consumed by all households in the Ahouandji locality is presented in Table 1. The total power of the load is estimated at $49,275 \mathrm{~kW}$ and the average daily energy consumption is $303,150 \mathrm{kWh}$.

Table 1. Average daily energy balance of the village

\begin{tabular}{|c|c|}
\hline Total power (kW) & $\begin{array}{c}\text { Average energy consumption } \\
(\mathbf{k W h})\end{array}$ \\
\hline 49.275 & 303.150 \\
\hline
\end{tabular}

\section{Selection of the micro wind power plant components}

The characteristics of the electrical equipment of the micro wind power plant are summarized in Table 2. The size of the wind farm is at least $24.5 \mathrm{~kW}$. The capacity of the battery bank is estimated at 15,790 Ah. The DC/AC converter has a power of at least $24.5 \mathrm{~kW}$. The power of the inverter-charger is estimated to be $62.85 \mathrm{~kW}$

Table 2. Essential characteristics of the micro wind power plant components

\begin{tabular}{|c|c|c|c|c|}
\hline Designation & Quantity & \multicolumn{3}{|c|}{ Characteristics } \\
\hline \multirow{8}{*}{ Wind turbine } & \multirow{8}{*}{03} & \multirow[t]{3}{*}{$\begin{array}{l}\text { Operating } \\
\text { Parameters }\end{array}$} & $\begin{array}{l}\text { Starting wind speed } \\
\mathrm{V}_{\mathrm{d}}(\mathrm{m} / \mathrm{s})\end{array}$ & 2.5 \\
\hline & & & $\begin{array}{l}\text { Nominal wind speed } \\
V_{n}(m / s)\end{array}$ & 6.8 \\
\hline & & & $\begin{array}{l}\text { Wind speed at cut-off } \\
\mathrm{V}_{\mathrm{c}}(\mathrm{m} / \mathrm{s})\end{array}$ & 16 \\
\hline & & Generator & Type & $\begin{array}{l}\text { Permanent } \\
\text { magnet } \\
\text { synchronous }\end{array}$ \\
\hline & & & Nominal power Pn (kW) & 9.9 \\
\hline & & & Number of blades & 3 \\
\hline & & Blade & Blade length (m) & 6.6 \\
\hline & & & $\begin{array}{l}\text { Surface swept by the } \\
\text { propeller }\left(\mathrm{m}^{2}\right)\end{array}$ & 136.7 \\
\hline & & & Nominal power Pn (kW) & 10 \\
\hline $\begin{array}{l}\text { Converter } \\
\text { DC/AC three- }\end{array}$ & 03 & & $\begin{array}{l}\text { Maximum input voltage } \\
\text { (V) }\end{array}$ & 1000 \\
\hline & & & Rated voltage AC (V) & $380-400$ \\
\hline
\end{tabular}




\begin{tabular}{|l|c|l|c|}
\hline \multirow{2}{*}{$\begin{array}{l}\text { Inverter- } \\
\text { Charger }\end{array}$} & 06 & $\begin{array}{l}\text { Maximum AC input } \\
\text { power (kW) }\end{array}$ & 11.5 \\
\cline { 3 - 4 } & 120 & $\begin{array}{l}\text { Maximum charge and } \\
\text { discharge current of the } \\
\text { batteries (A) }\end{array}$ & 51 \\
\hline Battery & 03 & Capacity (Ah) & 3000 \\
\hline Cable & 01 & Operating voltage (V) & 2 \\
\hline \multirow{2}{*}{$\begin{array}{l}\text { Device for } \\
\text { protection }\end{array}$} & 01 & $\begin{array}{l}\text { Three-phase differential } \\
\text { circuit breaker (A) }\end{array}$ & 60 \\
\cline { 2 - 5 } & 016 et 50 \\
\hline
\end{tabular}

Based on the power curve of the selected wind turbine (TN 535 from the manufacturer Tozzi Green), the monthly energy production of the micro wind power plant has been evaluated and presented in figure 7 .

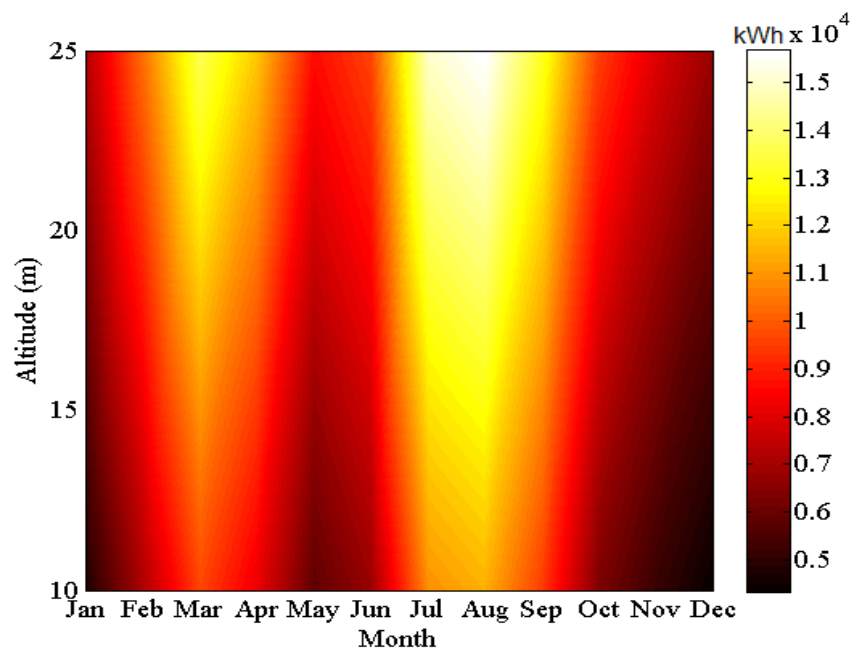

Figure 7. Monthly energy production of the micro wind power plant

It can be seen in Figure 7 that the energy production of the wind turbines varies from 4338 $\mathrm{kWh}$ to $11424 \mathrm{kWh}$ at $10 \mathrm{~m}$ and from $6792 \mathrm{kWh}$ to $15663 \mathrm{kWh}$ at $25 \mathrm{~m}$. The total annual energy production of the micropower plant is estimated at $129,528 \mathrm{kWh}$, or $355 \mathrm{kWh}$ on average per day. This production largely covers the average daily consumption of the village estimated at $303.15 \mathrm{kWh}$.

\section{Financial evaluation}

\section{Annual expenses}

The annual expenses for the construction of this micro wind power plant are summarized in Table 3. The initial investment takes into account the components of the micro wind power plant, the construction of a technical platform, the accessories of the low voltage network and the public lighting.

Table 3. Annual expenses of the micro wind power plant

\begin{tabular}{|c|c|c|c|c|}
\hline Designation & $\begin{array}{c}\text { Initial } \\
\text { investment } \\
\text { (euro) }\end{array}$ & $\begin{array}{c}\text { Maintenance and operating } \\
\text { costs (3\% of the investment) }\end{array}$ & $\begin{array}{c}\text { Overall } \\
\text { Annuity } \\
\text { (euro) }\end{array}$ & $\begin{array}{c}\text { discounted } \\
\text { cost (euro) }\end{array}$ \\
\hline $\begin{array}{c}\text { Micro power } \\
\text { plant }\end{array}$ & 123779.30 & 3713.38 & 17272.47 & 20985.85 \\
\hline
\end{tabular}




\section{Project Sustainability}

The result of the operation indicates that the cost price per kilowatt hour of electricity is 0.16 euro. For the operation of the plant, we have set the selling price of the kilowatt-hour at 0.17 euro for all social classes. This cost is quite competitive when compared to the tariff of the Société Béninoise d'Energie Electrique (SBEE) (0.19 euro/kWh), which is responsible for marketing energy in Benin. However, when comparing the cost per kilowatt hour obtained in this study to other costs observed in the literature by other authors on sites suitable for the installation of a wind power generation unit or plant, we note that the amounts vary according to the available potential, the size of the plant and the characteristics of the wind generators. Thus, by analyzing the work of Okeniyi et al [8] in Nigeria (Kaduna, Warri, Calabar), Ajayi et al [15] in Nigeria (Shaki and Iseyin in Oyo State), Gökçeka et al [16] in Turkey, Ahmed [17] in the East Red Sea coast of Egypt, Ajayi et al [18] in the southwestern region of Nigeria, Kassem et al [20] in two northern regions of Nigeria, and Kassem, et al [20] in the northwestern region of Nigeria. [22] in two regions of northern Cyprus, Gaddada and Kodicherla [21] in the Tigray region of Ethiopia, it is noted that the price of the kilowatt-hour has been evaluated respectively at $(0.0 .0507,0.0774,0.0819)$ euro; $(0.025,0.049)$ euro; (0.0537 to 0.119$) ;(0.013)$ euro; $(0.02$ to 5.03$)$ euro, $(0.023,0.04)$ euro; $(0.000093$ to 6.21$)$ euro. These different costs are mostly much lower than the cost obtained in this study. These differences would therefore be due to the fact that the sites do not have the same meteorological characteristics. Moreover, in the present study, except for the investment costs of the micro power plant, the costs related to the construction of a low voltage distribution network of the produced energy were taken into account in the calculation of the cost price of the kilowatt-hour contrary to the works met in the literature. The amortization time of the invested capital for the project was estimated at 06 years 184 days.

\section{Conclusion}

The characteristics of the components of a micro wind power plant were determined in the present study in order to supplying electrical energy to the populations of the locality of Ahouandji on the coast of Benin. Based on the statistical study of wind speeds recorded on this site and the socio-economic study of the population, the size of the micro wind power plant was sized. From the annual expenses generated by the construction, operation and maintenance of the plant, the price per kWh of electrical energy was estimated in order to assess the profitability of the project. The main results of this study are as follows:

(1) The mean annual wind speed is estimated at $4.51 \mathrm{~m} / \mathrm{s}$ at $10 \mathrm{~m}$ and $5.41 \mathrm{~m} / \mathrm{s}$ at $25 \mathrm{~m}$. The Weibull parameters (shape parameter k) vary from 2.23 to 3.97 and the scale parameter from $4.10 \mathrm{~m} / \mathrm{s}$ to $7.29 \mathrm{~m} / \mathrm{s}$ between 10 and $25 \mathrm{~m}$ from the ground. The mostfrequent velocity on the study site is $4 \mathrm{~m} / \mathrm{s}$ at $10 \mathrm{~m}$ and $5 \mathrm{~m} / \mathrm{s}$ at $25 \mathrm{~m}$ from the ground.

The speed giving the maximum energy varies from $7.53 \mathrm{~m} / \mathrm{s}$ to $11.19 \mathrm{~m} / \mathrm{s}$ between 10 and $25 \mathrm{~m}$.

(2) The micro power plant is composed of 03 wind generators with a respective power of $9.9 \mathrm{~kW}, 03$ three-phase DC/AC converters of $10 \mathrm{~kW}$ each, 06 inverter-chargers with a respective power of $11.5 \mathrm{~kW}, 120$ batteries of $3000 \mathrm{Ah} / 2 \mathrm{~V}, \mathrm{DC}$ and $\mathrm{AC}$ protection boxes and 03 three-phase differential circuit breakers of $60 \mathrm{~A}$

(3) The annual energy production of the plant has been estimated at $129,528 \mathrm{kwh}$ and fully covers the village's loads.

(4) The price per kilowatt hour of electricity is estimated at 0.17 euro and is quite competitive.

Based on these results, the installation of this micro power plant will be an asset for the locality of Ahouandji. 


\section{References}

[1] Soulouknga MH, Oyedepo SO, Doka SY, Kofane TC. Assessment of Wind Energy Potential in the Sudanese Zone in Chad. Energy and Power Engineering. 2017;09(07):386402. https://doi.org/10.4236/epe.2017.97026

[2] Donnou H, Akpo A, Nonfodji G, Kounouhewa B. Variability of Onshore Wind Energy Potential in the $60 \mathrm{~m}$ above the Ground under Convective Atmosphere in Southern Benin. American Journal of Energy Research. 2019 July;7(1):19-30. https://doi.org/DOI:10.12691/ajer-7-1-3

[3] Shawon M, El Chaar L, Lamont L. Overview of wind energy and its cost in the Middle East. Sustainable Energy Technologies and Assessments. 2013 06;2:1-11. https://doi.org/10.1016/i.seta.2013.01.002

[4] Qolipour M, Mostafaeipour A, Rezaei M. A mathematical model for simultaneous optimization of renewable electricity price and construction of new wind power plants (case study: Kermanshah). International Journal of Energy and Environmental Engineering. 2017 Nov 29;9(1):71-80. https://doi.org/10.1007/s40095-017-0254-4

[5] Wind Power Monthly. https://www.windpowermonthly.com/10- biggest-turbines. Accessed 2017 December 15.

[6] Global Wind Energy Council. http://gwec.net/wp content/uploads/2018/02/Global Cumulative Installed Wind Capacity 2001-2017.jpg. Accessed 2017 December 15.

[7] Global Wind Report 2018. www.gwec.ne. Accessed 2019 April.

[8] Okeniyi JO, Ohunakin OS, Okeniyi ET. Assessments of Wind-Energy Potential in Selected Sites from Three Geopolitical Zones in Nigeria: Implications for Renewable/Sustainable Rural Electrification. The Scientific World Journal. 2015;2015:1-13. https://doi.org/10.1155/2015/581679

[9] Donnou HEV, Boro D, Abode D, Capo-Chichi B, Akpo AB. Design of Vertical Axis Wind Turbine Darrieus Type (H- Darrieus Rotor) of $0.20 \mathrm{KW}$ from the Software Topsolid. Physical Science International Journal. 2020 Dec 31;:52-70. https://doi.org/10.9734/psii/2020/v24i1130227

[10] Awanou CN, Degbey JM, Ahlonsou E. Estimation of the mean wind energy available in Benin (Ex Dahomey). Renewable Energy. 1991 01;1(5-6):845-853.

https://doi.org/10.1016/0960-1481(91)90037-p

[11] Houekpoheha M, Kounouhewa B, Tokpohozin B, Awanou C. Estimationde la puissance énergétique éolienne à partir de la distribution de weibull sur la côte béninoise de Cotonou dans le golfe de guinée. Revue des Energies Renouvelables. 2014 September;13(3):489495.

[12] Akpo A, Damada J, Donnou H, Kounouhewa B, Awanou C. Estimation de la production énergétique d'un aérogénérateur sur un site isolé dans la région côtière du Bénin. Revue des Energies Renouvelables.18(3):457-468.

[13] Salami AA, Ajavon ASA, Kodjo MK, Bedja K. Evaluation of wind potential for an optimum choice of wind turbine generator on the sites of Lomé, Accra, and Cotonou located in the gulf of Guinea. International Journal of Renewable Energy Development. 2016 Nov 04;5(3):211223. https://doi.org/10.14710/ijred.5.3.211-223

[14] Abdelhady S, Borello D, Santori S. Economic Feasibility of Small Wind Turbines for Domestic Consumers in Egypt Based on the New Feed-in Tariff. Energy Procedia. 2015 08;75:664-670. https://doi.org/10.1016/j.egypro.2015.07.482 
[15] Ajayi O, Fagbenle O, Katende J. Assessment of Wind Power Potential and Wind Electricity Generation Using WECS of Two Sites in South West, Nigeria. International Journal of Energy Science. 2011 January;1(2):78-92.

[16] Gölçek M, Erdem HH, Bayülken A. A Techno-Economical Evaluation for Installation of Suitable Wind Energy Plants in Western Marmara, Turkey. Energy Exploration \& Exploitation. 2007 Dec;25(6):407-427. https://doi.org/10.1260/014459807783791791

[17] Ahmed AS. Wind energy as a potential generation source at Ras Benas, Egypt. Renewable and Sustainable Energy Reviews. 2010 Oct;14(8):2167-2173. https://doi.org/10.1016/j.rser.2010.03.006

[18] Ajayi O, Fagbenle R, Katende J, Ndambuki J, Omole D, Badejo A. Wind Energy Study and Energy Cost of Wind Electricity Generation in Nigeria: Past and Recent Results and a Case Study for South West Nigeria. Energies. 2014 Dec 22;7(12):8508-8534. https://doi.org/10.3390/en7128508

[19] Faida H, Saadi J, Khaider M, El Alami S, Monkade M. Etude et Analyse des Données du vent en Vue de Dimensionner un Système de Production d'Energie Eolienne: Cas d'un Site au Nord du Maroc. Revue des Energies Renouvelables. 2010 June;13(3):477-483.

[20] Kassem Y, Gökçekuş H, Çamur H. Economic assessment of renewable power generation based on wind speed and solar radiation in urban regions. Global Journal of Environmental Science and Management. 2018 Oct;4(4).

https://doi.org/10.22034/gjesm.2018.04.007

[21] Gaddada S, Kodicherla SPK. Wind energy potential and cost estimation of wind energy conversion systems (WECSs) for electricity generation in the eight selected locations of Tigray region (Ethiopia). Renewables: Wind, Water, and Solar. 201603 17;3(1). https://doi.org/10.1186/s40807-016-0030-8

[22] Bagiorgas H, Assimakopoulos M, Theoharopoulos D, Matthopoulos D, Mihalakakou G. Electricity generation using wind energy conversion systems in the area of Western Greece. Energy Conversion and Management. 2007 05;48(5):1640-1655.

https://doi.org/10.1016/j.enconman.2006.11.009

[23] Hounguè $\mathrm{GH}$, Kounouhéwa BB, Tokpohozin BN, Houékpohéha MA, Madogni VI, Almar R. Wave Energy Impact on Benin's Coastline Dynamics, Gulf of Guinea. Current Journal of Applied Science and Technology. 2018 Nov 13;30(4):1-12. https://doi.org/10.9734/cjast/2018/44341

[24] Cahier des villages et quartiers de ville du département de l'Atlantique, Bénin. INSAE; 2016.

[25] Donnou HEV, Akpo AB, Kouchadé CA, Kounouhewa BB, Hounguè GH, Nonfodji GF, Djossou J. Vertical Profile of Wind Diurnal Cycle in the Surface Boundary Layer over the Coast of Cotonou, Benin, under a Convective Atmosphere. Advances in Meteorology. 2019 04 01;2019:1-18. https://doi.org/10.1155/2019/7530828

[26] Akinsanola A, Ogunjobi K, Abolude A, Sarris S, Ladipo K. Assessment of Wind Energy Potential for Small Communities in South-South Nigeria: Case Study of Koluama, Bayelsa State. J Fundam Renewable Energy Appl. 2017 February;7(2):1-6. https://doi.org/10.4172/20904541.1000227

[27] Fadare A. A statistical analysis of wind energy potential in Ibadan, Nigeria, based on Weibull distribution function. Pac J Sci Technol. 2008;9(1):110-119.

[28] Koukpémédji A. Sur le potentiel énergétique éolien en milieu tropical: Cas du Bénin. Porto Novo, Bénin: Université d'Abomey-Calavi, Institut de Mathématiques et de Sciences de Physiques; 2015. 
[29] Weisser D. A wind energy analysis of Grenada: an estimation using the 'Weibull' density function. Renewable Energy. 2003 09;28(11):1803-1812. https://doi.org/10.1016/s09601481(03)00016-8

[30] Merzouk N, Merzouk M. Estimation du Potentiel Energétique Eolien Utilisable Application au Pompage dans les Hauts Plateaux. Revue des Energies Renouvelables. 2006 January;9(3):155-163.

[31] Gnandji M, Fifatin F, Dubas F, Espanet C, Vianou A. Etude du Potentiel Energétique Eolien Offshore du Bénin. Cotonou, Benin: Colloque International Francophone portant sur l'Energétique et la Mécanique; 2018 November.

[32] Newman J, Klein P. The Impacts of Atmospheric Stability on the Accuracy of Wind Speed Extrapolation Methods. Resources. 201401 23;3(1):81-105. https://doi.org/10.3390/resources3010081

[33] Gualtieri G. Atmospheric stability varying wind shear coefficients to improve wind resource extrapolation: A temporal analysis. Renewable Energy. 2016 03;87:376-390. https://doi.org/10.1016/j.renene.2015.10.034

[34] Okorie ME, Inambao F, Chiguvare Z. Evaluation of Wind Shear Coefficients, Surface Roughness and Energy Yields over Inland Locations in Namibia. Procedia Manufacturing. 2017;7:630-638. https://doi.org/10.1016/j.promfg.2016.12.094

[35] Morel Aolo S. Etude de l'électrification décentralisée par une microcentrale solaire photovoltaïque: cas de la localité de Koutè, commune de Ségbana. Abomey-Calavi, Bénin: Energies Renouvelables et Systèmes Energétiques, Université d'Abomey-Calavi; 2014.

[36] Adaramola MS, Agelin-Chaab M, Paul SS. Assessment of wind power generation along the coast of Ghana. Energy Conversion and Management. 2014 01;77:61-69.

https://doi.org/10.1016/.enconman.2013.09.005

[37] Udo N, Oluleye A, Ishola K. Investigation of Wind Power Potential over Some Selected Coastal Cities in Nigeria. Innovative Energy \& Research. 2017;06(01).

https://doi.org/10.4172/2576-1463.1000156 